\title{
TRES SÍMBOLOS Y UNA METÁFORA EN LA POESÍA DE ANDRÉS SÁNCHEZ ROBAYNA
}

Alejandro RODRÍGUEZ-REFOJO

$\mathrm{T}$

Tarde o temprano, todo poeta que conciba su labor como una aventura orientada en mayor o menor medida hacia lo íntimo del hombre (en el sentido etimológico de la palabra: intimus, lo más interior), o que conciba su trabajo de creación como un proceso de búsqueda en el que lo interior desea convertirse en mundo y el mundo anhela volverse lugar interior, mundo visible e invisible que podríamos nombrar tomando prestado el concepto rilkeano de «espacio interior del mundo» (Weltinenraum), ese poeta, digo, se encontrará tarde o temprano con el problema de cómo expresar y construir el interior de la palabra. Uno de los aspectos íntimamente relacionados con este problema es el del símbolo.

Andrés Sánchez Robayna es uno de los pocos poetas que, en el panorama lírico español de los últimos cuarenta años, se ha visto llevado, de modo necesario debido al desarrollo de su escritura y de su pensamiento poético, a la creación de lo que podemos llamar un espacio simbólico. Este espacio se sustenta en el espacio metafórico previamente construido por el poeta a partir de una realidad física muy concreta; espacio primero que viene dado por un conjunto de elementos y de imágenes característicos: la roca y las aguas, la casa, las nubes, la noche estrellada, la barca, el vaso de agua, los médanos, el ramaje, la montaña, etc.

Pero es sólo a partir de Palmas sobre la losa fría (1989) cuando esas imágenes penetran, a mi entender, en un espacio nuevo que enriquece el espectro interpretativo de su poesía y que podemos llamar sin género de duda simbólico. Poemas como «La estrella», «Una piedra, memoria», «Sobre una piedra extrema» o «En el centro de un círculo de islas» dan cuenta del conflicto, vamos a llamarlo así, que acontece entonces en la poesía de Sánchez Robayna y que se expresa a través de diferentes símbolos. Llamaremos a ese conflicto primordial la lucha entre la belleza y la caducidad, entre la muerte y la memoria, entre el orden y el caos — resuelta en armonía en algunos de estos poemas, manifiesta en toda su tensión en otros.

Del conjunto de imágenes que conforman ese espacio he seleccionado los símbolos de la barca, la casa (el templo) y la piedra. Están fuertemente anudados, hasta el punto de que no es posible realizar un análisis separado de uno de ellos sin que la comprensión de la poesía de Sánchez Robayna no se vea seriamente mermada o limitada. Los tres están ligados o, mejor dicho, cosidos 
con un hilo muy fino; los tres, a su vez, vinculados a la metáfora de la luz y sus distintas manifestaciones. También examinaré, debido a su importancia, una imagen o motivo que los contiene a todos: el «libro del mundo». Para ello me centraré en los libros que configuran una segunda etapa en la poesía del autor, esto es, el trayecto que va de Palmas sobre la losa fría (1989) a Inscripciones (1999).

\section{El símbolo}

Una imagen adquiere la condición de símbolo si se constituye en representación de algún aspecto o dimensión relacionados con la interioridad más radical, con aquello que se resiste, dado su grado de ocultamiento respecto a la zona iluminada de la conciencia, a ser expresado mediante los modos convencionales del lenguaje. Se podría decir que el símbolo, más que representar un objeto o una experiencia, ilumina un haz de significaciones irreductibles entre sí que instaura un sentido no comunicable directamente, un sentido referido siempre al ámbito de lo trascendente. En palabras de Gilbert Durand: «el símbolo [...] es epifanía, es decir, aparición de lo inefable por el significante y en él.»; más concretamente, el símbolo es «una representación que hace aparecer un sentido secreto; la epifanía de un misterio.» (Durand, 2007: 14-15).

El símbolo así entendido surge propiamente en la poesía de Andrés Sánchez Robayna en Palmas sobre la losa fría (1989), si bien hay que advertir que ciertas imágenes, como la barca o la piedra, que ya aparecen en libros anteriores, poseen una naturaleza protosimbólica. Podemos vincular la aparición del símbolo a la concepción de la palabra poética como «misteriosofía» mencionada por el autor en distintos lugares de su obra. Entendido en su sentido más profundo, el símbolo es siempre religioso y pertenece en consecuencia, a causa de la serie conceptual que define su inasible objeto (inefabilidad, misterio, trascendencia), al ámbito de lo sagrado, como se verá al final de este escrito.

\section{La barca}

Como queda dicho, las configuraciones simbólicas más significativas de la poesía de Sánchez Robayna se apoyan en la red de imágenes tejida por el autor a lo largo del arco de escritura constituido por Clima (1978), Tinta (1981) y La roca (1984). Estos tres libros forman la firme base sobre la que se asienta su trabajo poético posterior. Uno de los rasgos que singularizan este tríptico es, precisamente, esa red de imágenes que podríamos llamar sistema imaginístico siempre que lo consideremos como un sistema abierto. Incluido en Tinta, el poema en prosa «Sistema» — que puede leerse como una reinterpretación en clave estructuralista del célebre poema «Correspondencias» de Baudelaire-, nos ofrece una imagen de lo quiero decir. Si vemos este poema en prosa como una serie de variaciones sobre un tema, en un sentido puramente musical, y aplicamos este modelo a la obra poética del autor, entonces podemos imaginarla y comprenderla como una serie de variaciones (imágenes) sobre un doble tema, la naturaleza y el libro — de Día de aire (1970) a Tríptico (1985)—, 
que se va desarrollando hasta engendrar una segunda serie (imágenes y símbolos) que incluye el tema del tiempo y la memoria - de Palmas sobre la losa fría (1989) a La sombra y la apariencia (2010).

Si abrimos ahora el libro La roca y leemos dos poemas que comparten título, «La barca», el primero integrado por tres fragmentos y el segundo por cuatro, vemos que la barca aparece en ellos como nota de un paisaje reducido a sus elementos esenciales: la roca, la arena, la playa, el cúmulo, el mar y las aguas, la luz, la retama, el sol, etc. Dentro del sistema de imágenes que este libro establece la barca no cumple una función simbólica, sino musical, y aunque pueda parecernos que en La roca, a diferencia de Tinta, predomina la dimensión visual de lo poético, lo cierto es que la musicalidad vertical de sus versos, concebida por el propio autor como litofonía ${ }^{1}$ (1996: 59) —una música entretejida de silencios y palabras que hace cierto el aforismo de Ory de que «sin previo silencio las palabras no suenan» (Ory, 2005: 110)—, es sin duda el componente que estructura íntegramente la composición del libro.

La barca se asocia a otros elementos para crear una variación sobre el gran tema de la naturaleza, contemplada en su radicalidad y escrita desde una concepción del lenguaje poético como «segunda naturaleza» (Sánchez Robayna, 1996: 59). La barca reaparecerá más tarde transformada en símbolo, asociada no al sol, sino al fuego, en Palmas sobre la losa fría. Destaquemos ahora, tan solo, el contexto en el que inserta la imagen de la barca. En el segundo de los poemas citados, alguien despierta y ve en la ventana unas barcas que «arrastran cordajes». Citaré los dos últimos fragmentos:

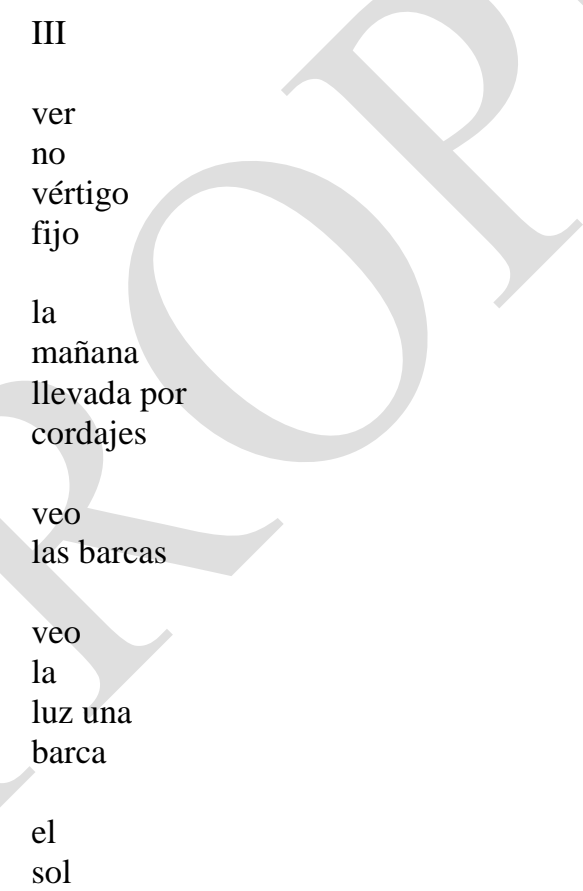

\footnotetext{
${ }^{1}$ Sánchez Robayna se ha referido a los poemas de La roca como poemas litofónicos: «El poema ha de tener la forma de un grupo de rocas. Percusión de la roca: poema litofónico. El sonido del enigma del ser.» (Sánchez Robayna, 1996: 59). Este designio, el de una palabra poética concebida en su pura materialidad, no como cosa, sino como enigma material, converge con una concepción del mundo como materialidad enigmática, de la que da fe su libro Clima. Lo que el autor ha llamado «la pregunta por la palabra» (2008: 331-344) se inscribe precisamente en esa convergencia.
} 


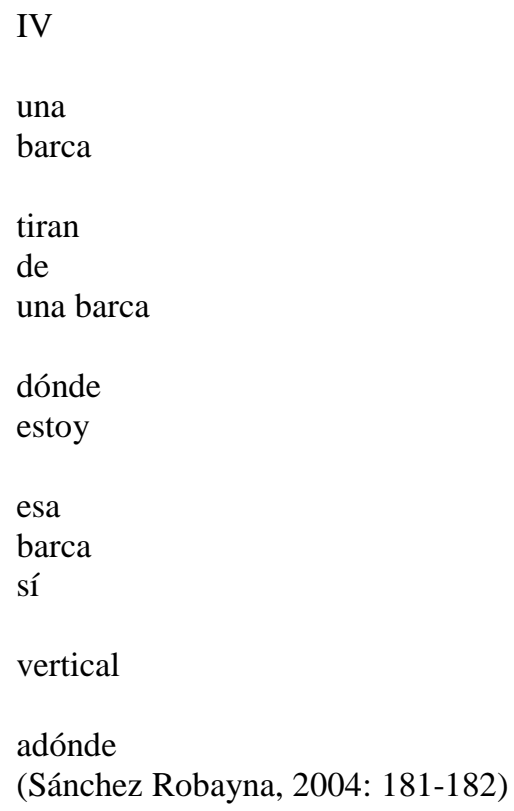

Interesa destacar la tenue oposición que se establece entre las barcas y la «barca vertical». El valor que esta posee es doble: representa la unidad de la luz y la unidad de la visión en el instante: «veo / la / luz una / barca». Pero ¿qué nexo vincula la barca con la luz del sol de la mañana? ¿Y los cordajes? ¿Son solo eso, las cuerdas que tiran de las barcas, o remiten a otra realidad? ¿Qué es lo que ven el poeta y el lector? ¿Solo unas barcas, el sol, los cordajes, el vértigo de la mirada?

Estas preguntas conducen a la postulación de una dimensión enigmática en La roca que supone, a mi juicio, la suspensión de la cerrada autorreferencialidad que caracteriza el movimiento de la palabra en Tinta. Esta dimensión enigmática o mistérica no se basa en ninguna forma de tecnificación de lenguaje: es una creación del lenguaje que apunta más allá de él, y asegura, de un modo no siempre claro, la conexión de la etapa que cierra La roca con la que abre su siguiente libro, Palmas sobre la losa fría. La visión de la palabra y el mundo como sistemas que señalan y encierran un enigma no descifrable es el puente que une las dos etapas creativas del autor, y uno de los elementos fundamentales y constantes de su poética.

Esta afirmación puede comprobarse si leemos ahora el poema «La barca de fuego» (incluido en Palmas sobre la losa fría) que transcribo completo.

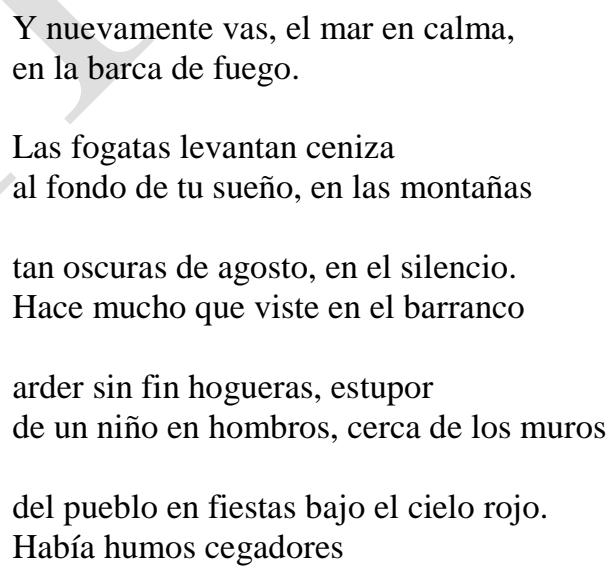




\title{
Alejandro Rodríguez-Refojo
}

\author{
en mitad de la noche de verano, \\ fuegos multiplicados en laderas

El poema da cuenta de un «recuerdo soñado» que transporta al poeta hasta un episodio de la infancia, el de unas hogueras festivas que arden en el barranco en mitad de la noche de verano - una reminiscencia de las fogatas de la noche de San Juan - y el de un niño fascinado que regresa dormido a casa y que despierta «al ruido de los pasos en la grava». El recuerdo de esa noche constituye el cuerpo del poema, que se halla enmarcado por la primera y la última estrofa. Estas introducen la referencia a la «barca de fuego», una imagen que, en principio, no parece estar conectada con el 'relato' del poema. Esto se debe a que la conexión es simbólica. Pero ¿por qué una barca?

El mito que subyace en el poema no es otro que el de la «barca solar» de la mitología egipcia. Para los antiguos egipcios, el ciclo de la llegada y la puesta del sol era comparable al ciclo de la vida y de la muerte. El dios solar Ra realiza en barca un viaje desde oriente hasta occidente, para luego desaparecer en la Duat, el reino de los muertos. El viaje diurno lo realiza a bordo de una barca llamada mandyet; el viaje nocturno o subterráneo, a bordo de otra barca, mesektet. En el reino de los muertos debe enfrentarse a la serpiente Apofis, que representa las fuerzas del caos.

En el poema de Robayna la «barca de fuego» atraviesa las aguas nocturnas llevando consigo el recuerdo de la luz de las hogueras y de la noche iluminada, de la misma forma que la barca solar atraviesa la noche para renacer al día siguiente. Solo que aquí la barca parece regresar a oriente: a un lugar y un momento concreto de la infancia. Puede decirse, entonces, que la barca en tanto vehículo constituye una imagen de la memoria que lleva al poeta hasta el recuerdo de las hogueras, e incluso 
más allá, hasta el umbral de «la vieja casa» — la casa familiar que, según Bachelard (2000: 29), «protege al soñador [y le] permite soñar en paz». El propio poeta (1996: 125) se da cuenta de ello después de escribir el poema: «De pronto, como un golpe imprevisto, caigo en la cuenta de que la barca de fuego, expresión a la que yo casi me resistía, no es otra cosa que la memoria.»

La barca que aparece en La roca es un elemento estático; la barca que surge en Palmas sobre la losa fría se mueve por las aguas del sueño, es un vehículo que transporta el fuego de la memoria. La imagen de la barca se transforma, así, en símbolo, no de una facultad abstracta del espíritu o de la mente, sino de una experiencia concreta del mundo que va a constituir uno de los caminos por los que va a transitar la poesía de Sánchez Robayna desde Palmas sobre la losa fría hasta la actualidad. En este sentido, la memoria y sus actos, tanto voluntarios como involuntarios, van a convertirse en formas de ese misterio que se expresa en la escritura órfica de la tierra y que rige la poesía entera del autor desde sus comienzos, así como en elementos fundamentales del giro o variación que, después de La roca, se produce en su trayectoria poética, una vez atravesado lo que el poeta llamó el «purgatorio de la palabra» (1996: 165), es decir, una fase de su escritura marcada por una indagación radical en la materialidad de la palabra poética.

Esta variación se esconde en otro de los valores simbólicos de la imagen de la barca, según se desprende del clima del poema. Este clima autoriza a ver el poema como un «sueño acunado», según la expresión de Gaston Bachelard (2003: 200), y la barca como «una cuna recuperada» (2003: 200), pues sólo el agua puede acunar «como una madre» (2003: 199). Más aún, la barca es un «claustro materno» (Cirlot, 1997: 107). El poema «La barca de fuego» puede también interpretarse, de este modo, como un renacimiento simbólico-poético operado a través de esa barca-cuna-seno materno, que llevará al poeta a introducir en su poesía materiales experienciales excluidos de sus primeros libros en razón de aquella «desaparición elocutoria del poeta» preconizada por Mallarmé, desaparición que, como sabemos, constituyó uno de los fundamentos de la poética primera de Robayna.

La barca de fuego tiene aún otro significado simbólico más profundo. Pero antes es preciso analizar algunos aspectos del poema «Para la llama de una vela», que se dispone inmediatamente después de «La barca de fuego». En aquel poema se da una situación en la que los símbolos primordiales de la oscuridad y la luz entablan una lucha dialéctica, resuelta de modo magistral en el último verso del poema: «la luz oscura». Este oxímoron final, preparado a lo largo del poema por imágenes como «luz / de oscuridad», se relaciona con la expresión «saber de un no saber» del poema «Las primeras lluvias», así como con el leitmotiv de la «nube del no saber» que aparece en El libro, tras la duna, y todas ellas con la «nada» del poema «Reflejos en el día de año nuevo» (La sombra y la apariencia, 2010). Este orden de significación remite al conocimiento negativo de la Teología mística del Pseudo Dionisio, según el cual el único saber posible acerca de la divinidad es el «no saber». Es importante tener presente esta idea porque constituye un elemento fundamental de la cosmovisión del autor y porque se halla íntimamente relacionada con la naturaleza del símbolo y con la concepción de la memoria: «El acto de la memoria penetra igualmente en lo desconocido», afirma 


\section{Alejandro Rodríguez-Refojo}

el poeta en una anotación de los Diarios (1996: 201). Los actos de la memoria representan también, como los de la palabra, un modo de conocimiento por enigma.

La imagen de la barca retiene aún, en la poesía de Robayna, un significado simbólico que encuentra en el poema «En el centro de un círculo de islas» (La sombra y la apariencia) una formulación muy clara. El poema habla de una barca que avanza por el mar hacia una isla: Delos, la isla flotante que, según el mito griego, fue fijada al fondo del mar por Zeus para que Leto diera a luz a Apolo y Artemisa. La isla consagrada al dios es el «fin fiel» de la barca y del viaje, el «sueño de la tierra». Delos es:

$$
\begin{aligned}
& \qquad \ldots] \text { el fin } \\
& \text { de lo que yace en ti, de todo lo que en ti } \\
& \text { brota y se extingue, } \\
& \text { eres la tierra toda, isla que nos contienes, } \\
& \text { isla a la que avanzamos y que vemos venir } \\
& \text { a nuestro encuentro } \\
& \text { en el centro de un círculo de islas. } \\
& \text { (Sánchez Robayna, 2010: 135) }
\end{aligned}
$$

Si en el poema «La barca de fuego», esta parece remontar el tiempo hasta la infancia, la barca de «En el centro de un círculo de islas» avanza hacia occidente, hacia un fin y un origen que simbolizan un centro. La isla es, de modo evidente aquí, un «eje del mundo»: isla-centro de un círculo de islas porque, como observa Helena Tur Planells (2006: 99), «cuando uno se acerca a la isla poco a poco se dibuja en el subconsciente un modo de ser circular».

Ese «fin» que representa la isla sagrada de Delos no es otro que la muerte. La muerte y su «tormento», pero también la salvación inherente a todo simbolismo del centro, porque en este poema la imagen de la isla tiene la virtud de mantener en toda su tensión ambos significados simbólicos. De hecho, la imagen de la barca nos haría pensar en el simbolismo de la barca funeraria si no fuera por el esplendor lumínico que envuelve el poema. Salvando las distancias, podría decirse que «En el centro de un círculo de islas» constituye el doble luminoso del célebre cuadro de Arnold Böcklin, $L a$ isla de los muertos.

En cualquier caso, importa hacer visible el hilo secreto que une la imagen de la barca y la isla. Como señala Cirlot (1997: 329), «se ha relacionado la nave, como símbolo, con la isla sagrada, en cuanto ambas se diferencian del mar amorfo y asaltante. Si las aguas oceánicas simbolizan el inconsciente, también aluden a la sorda agitación del mundo exterior». La barca presupone la llegada a la isla y, en cierto modo, la anticipa. En la medida en que representa a la propia isla, la barca constituye un «centro» en movimiento. Pues aquella se mueve igual que la barca por las aguas del sueño: «Tierra del nacimiento y la extinción, / ¿a dónde avanzas tú?» (Sánchez Robayna, 2010: 135).

\section{La casa}

El símbolo de la casa no tiene una presencia continua a lo largo de la trayectoria poética de Sánchez Robayna. Aparece de forma puntual en unos cuantos poemas de Palmas sobre la losa fría y 
de Fuego blanco. Sin embargo, esa presencia se revela significativa si la observamos bajo la luz de la visión del mundo y la poética del autor.

El primer poema en el que aparece es «La estrella». Observemos de entrada que el título del poema no es «La casa», sino «La estrella», imagen que entabla con aquella una suerte de diálogo:

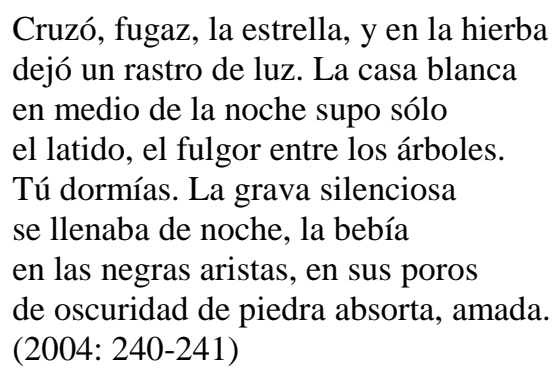

Tras salir al jardín siguiendo el rastro de la estrella y leer con demora los signos nocturnos, el yo poético entra en la casa y ve, de pronto, la estrella. El hecho de salir en busca de la estrella y de hallarla dentro posee claras y hondas resonancias místicas. La presencia de los poemas mayores de san Juan de la Cruz y el más lejano «yo duermo, pero mi corazón vela» (Cant. 5:2, Nácar-Colunga) del Cantar de los cantares bíblico es innegable. Imposible no recordar los versos de la «Noche oscura» sanjuanista: «salí sin ser notada, / estando ya mi casa sosegada» (Noche oscura, I, 1).

No debe perderse de vista, por otro lado, el verso que encabeza el poema a modo de cita, «Non dormia, e cuydava», que pertenece a la cantiga de amigo «Lelia doura», del poeta Pedr'Eanez Solaz. La cantiga, que es una alborada, nos permite afirmar que estamos, en parte, en presencia de un poema amoroso. El «eros de la nominación» (Sánchez Robayna, 2008: 339) que singulariza la primera etapa poética del autor se halla inserto ahora en un contexto creativo distinto. Hay que subrayar este hecho porque el poema posee distintas facetas y soporta varias interpretaciones.

Lo que interesa subrayar, sin embargo, es que la imagen de la casa surge en este poema como un símbolo del «orden» del mundo, un símbolo del cosmos. La casa es, pues, en tanto microcosmos, otra manifestación del axis mundi, como intentaré mostrar. Este símbolo mantiene, por otro lado, una relación estrecha con el cuerpo que es preciso señalar, debido a la materialidad o corporalidad que definen en otro plano la poesía del autor. Como señala de forma acertada Jean Hani (2005: 231),

La morada del hombre es una prolongación de su cuerpo, y no sólo de su cuerpo, sino de él todo entero y de esa ampliación de sí mismo que es su familia, al mismo tiempo que una porción, selecta, del mundo, de la tierra que él ha cavado para plantar en ella su cuerpo al mismo tiempo que ese cuerpo mayor que es su casa.

En lugar de la oposición cuerpo-alma que impregna la moral y la teología cristianas, encontramos en este poema un diálogo dentro-fuera —o arriba-abajo — que debe entenderse a la luz de la tradición hermética, cuya imago mundi, presidida por el símbolo, la analogía y la relación especular entre el hombre (microcosmos) y el universo (macrocosmos), impregna y atraviesa el neoplatonismo renacentista hasta llegar a nuestros días. 


\section{Alejandro Rodríguez-Refojo}

Siguiendo el hilo de este circuitus spiritualis, y a tenor de lo ya dicho, la estrella podría simbolizar el «alma del mundo» que late también en el interior del ser humano como signo o señal de una interioridad lumínica que da sentido al propio mundo y a la existencia, pues en realidad es la imagen conjunta de la casa y la estrella el núcleo simbólico que estructura el poema. Para su interpretación quisiera destacar los versos siguientes:

Fui por la hierba hasta las agitadas
acacias, hasta el muro, y una calma
llenaba el aire aun en la agitación
y en la inquietud de los ramajes, clara
calma en la hierba, y contra el muro puse
la mano en su quietud. Tocaba el mundo.
Tocaba un orden, una calma, el aire
entre el mar y la acacia, y recordaba
tal vez la luz y su destino oscuro.
Entré. Volví a mirar la hierba, el cielo,
la casa silenciosa. Allí tu cuerpo
brilló en la oscuridad. Y vi la estrella.
(2004: 241)

El acto de tocar el muro de la casa es equivalente al acto de tocar el mundo, porque la casa es, como lo es también el templo, una imagen simbólica del centro del universo y, por tanto, de su orden sagrado. Un orden «cósmico» que integra la oscuridad de la noche y la luz de la estrella en una unidad armónica de indudable fuerza y belleza. El acto de poner la mano un momento sobre el muro supone una participación en ese orden cósmico y encierra además un sentido erótico que no resulta del todo evidente. A través de ese contacto mundo y hombre son, por un instante, una sola cosa, de tal modo que el yo poético se encuentra ya «en el cuerpo del mundo» y así le es posible hallar «la estrella» al penetrar en él.

La imagen de la casa reaparece en el poema «Una luz, ante la casa». La escena es similar a la anterior. Los elementos básicos que la configuran son los mismos: la casa en medio de la noche, un rumor y una luz que «llaman» al poeta al exterior, una calma y un orden percibidos como enigmáticos. Sin embargo, ese orden y esa calma están llenos ahora de tensión, a diferencia de la armonía cósmica que preside el desarrollo de «La estrella». Se trata ahora de una armonía de tensiones opuestas, patente no solo en las imágenes del poema, sino también en su sintaxis versal. También vemos de nuevo la imagen de la barca, pero esta vez vacía: «Oquedad / de la barca sin nadie» (2004: 266), tirada por los mismos «cordajes» que aparecen en el ya comentado poema de $L a$ roca.

Pero el verso sobre el que quiero llamar la atención es este: «Allí estaba la casa, contra la noche sola.» (2004: 266). Los dos hemistiquios de este verso y la preposición «contra» concentran gran parte de la carga simbólica del poema, que mantiene con otro poema del libro, «Una piedra, memoria», ciertas correspondencias que quiero subrayar. En efecto, los poemas que integran la obra 
poética de Andrés Sánchez Robayna guardan relaciones entre sí, tienden hilos o «cordajes» entre ellos, se llaman unos a otros.

El mundo de la noche y el de la casa parecen, así pues, oponerse. No se produce una integración de ambos mundos ni una síntesis de la dialéctica dentro-fuera, como sucede en «La estrella». La casa se erige también aquí en símbolo de un «orden», y aunque su significado es ambivalente, todavía retiene, en mi opinión, su carácter de axis mundi, su valor como «centro». La aparición de un signo lumínico («una luz») se percibe ahora como un enigma inquietante al que apuntan todas las imágenes del poema: el rumor, la sombra del ramaje, la oquedad de la barca, los pasos del caminante, la noche agolpada en el umbral. Las tensiones imago-sintácticas del poema se reproducen en el plano simbólico: la casa se contrapone a la noche en la medida en que esta, como imagen tradicional del olvido y la muerte, contradice el «orden» que la casa simboliza en tanto morada del hombre, en tanto emblema de la estabilidad de las cosas.

Esta contraposición y las tensiones que rigen el poema, bajo las cuales es posible atisbar una angustia latente, explican que la «luz» permanezca fuera de la casa como algo incierto y desconocido, así como la «oquedad» de la barca, imagen contrapuesta a la de la «barca de fuego» que, como queda dicho, puede ser considerada un símbolo de la memoria. Ahora puede verse la conexión secreta que existe entre la «barca» y la «casa» en la poesía de Sánchez Robayna. Las funciones de ambos símbolos son similares: construir una especie de orden interior frente al caos que significa la caída en el tiempo y la conciencia de la caducidad. Si el libro Fuego blanco fija esta caída en la trayectoria poética y vital del autor, la imagen de la casa como centro cumple una función que ahora se nos aparece con total claridad y que podemos formular con las palabras de Josep Maria Esquirol: hacer «que el mundo no sea ni caos ni dispersión total» (2015: 41).

La noche tiene, no obstante, valores simbólicos positivos. Está muy vinculada a la idea de belleza y también a la de orden cuando se asocia a las estrellas y las constelaciones, como puede comprobarse en la imagen del «cielo estrellado» que vemos aparecer en El libro, tras la duna, así como en «La estrella», e incluso en el poema «La ventana: estrellas» de La roca. Además, la noche hace posible la escucha de la palabra y el encuentro con la luz. Pero esa escucha se realiza desde un lugar: la casa, de la cual se sale o en cuyo umbral se permanece. La oposición que me parece ver en «Una luz, ante la casa» se hace explícita en otro poema de Fuego blanco, «Una piedra, memoria», que inaugura la reflexión sobre el tiempo y la conciencia del fin en la poesía del autor, y en el que puede leerse: «La casa / fue siempre cosa de la luz. / Desde aquel día supo de la sombra, o su signo.» (2004: 269-270).

Volveré a este importante poema. Baste por ahora decir que la asociación de la casa con la luz remite a este haz de significaciones, y nos hace además releer el poema «La barca de fuego» con otros ojos. Ahora vemos que la «vieja casa» de este poema - la casa natal probablemente - posee in nuce el mismo valor simbólico que las casas que aparecen en «La estrella», «Una luz, ante la casa» y en «Una piedra, memoria». «La barca de fuego» no es sino el vehículo simbólico del regreso, y representa de modo abreviado el lugar al que se orienta: la isla, la casa y, también, el templo. 

Alejandro Rodríguez-Refojo

Esta red de asociaciones simbólicas se hace ya evidente en uno de los más hermosos poemas escritos por el autor, «La capilla», que pertenece a su libro Inscripciones (1999), publicado siete años después de Fuego blanco. Está integrado por doce fragmentos y se inspira en una visita del autor a la capilla del King’s College en Cambridge. El fragmento III dice así:

¿Qué te trajo hasta aquí?

No esperabas hallar bajo estos cielos
este otro espacio que te acoge
como seno materno, como casa
en que el ser se refugia ante la tempestad
y es apresado por la luz,
y se convierte en luz
reclinada en los muros, y se junta
a la que se desliza
con suavidad por las vidrieras,
y a través del color es el color
y a través de la luz es transparencia.
(2004: 352 )

La imagen del templo «como casa» no debe parecer extraña. Como señala Jean Hani reflexionando sobre la sacralidad de la morada, «del templo a la casa no hay realmente discontinuidad, muy al contrario; a niveles diferentes, se trata de edificios semejantes y de la misma naturaleza» (2005: 231). Las notas de protección y cobijo son, en efecto, comunes a ambos símbolos. El templo es también un «seno materno», imagen que actualiza uno los aspectos tradicionales del símbolo de la casa: el de representar el aspecto femenino del universo. Por otro lado, ese templocasa, que ofrece refugio «ante la tempestad» del mundo y la vida, nos recuerda que, en el simbolismo cristiano, la nave representa a la iglesia.

Aunque en «La capilla» no vemos aparecer la imagen de la barca, esta se halla implícita en el simbolismo general del poema. En una temprana anotación de sus Diarios, fechada en abril 1985, Sánchez Robayna transcribe una reflexión de Eliade que es de suma importancia para desentrañar el significado de los tres símbolos que aquí se analizan. Repasando el Diario de Eliade, el poeta anota (1996: 81):

Pero encuentro también, al azar, una frase que subrayé entonces y que vuelve a entusiasmarme ahora, creo que en relación con mi poema «La barca» (de La roca): «El templo griego se llama naos, néos - como la barca». Y, en seguida: «El Templo, es decir, la sacralidad expresada en volúmenes, está concebido como una barca, gracias a la cual se puede viajar (evidentemente hacia el cielo, en el cielo), se puede atravesar las aguas (el no ser, las tinieblas, el caos, etcétera). La idea de ... la travesía perfecta es una forma cerrada que protege ... de la disolución (disolución en las Aguas).»

Recuerdo del arca de Noé y de la barca de Pedro, el templo cristiano es, pues, una barca. Tanto esta como aquel representan en la poesía de Robayna un axis mundi, ya que, como afirma Cirlot (1997: 289), el simbolismo de la nave se asocia «con todos los del "eje del mundo"; el mástil colocado en el centro del navío da realidad al árbol cósmico integrado en la nave funeraria o "barco de la trascendencia".» 
Pensemos ahora en aquella «barca vertical» de La roca. El eje vertical de esta barca inmóvil (luz-espacio) y el eje horizontal (tiempo-memoria) que vemos dibujarse en la barca como vehículo confluyen en el símbolo de la «barca de fuego». Desde una óptica simbólica este hecho justifica la asimilación — no la identidad — de las imágenes de la barca, la casa y el templo. Estas aparecen en la obra de Robayna, en tanto «formas cerradas» que protegen de la «disolución», revestidas de su valor tradicional de «eje del mundo»,

Pero lo más atrayente de este poema, que actualiza algunos de los aspectos más interesantes del simbolismo del templo cristiano, es la manera en que la capilla aparece como una imagen del cosmos. Tatarkiewicz sintetiza así el sentido que esta analogía tenía en la arquitectura cristiana medieval: «el techo simbolizaba el cielo, por cuanto este era extenso y abovedado; su cúpula representaba la cúpula celeste, y sus cuatro arcos, finalmente, los cuatro puntos cardinales.» (2007: 35). De este rico simbolismo bebe en efecto el poema, en el que vemos reaparecer esa dialéctica dentro-fuera característica de «La estrella», así como del poema titulado «La casa»—el poema final del libro Fuego blanco:

\footnotetext{
Salir hasta la casa, entrar hacia afuera, a la luz, hasta las aguas en la espesura adentro en las arenas de adentro de esta casa en que morir. (2004: 298)
}

¿De qué casa habla el poeta? ¿De su propia casa, del mundo, de uno de los mundos que componen el universo, del libro que es un mundo? De todos esos ámbitos a la vez. Mucho tiempo después de escrito este breve poema encontramos la siguiente reflexión, que constituye el nudo del fragmento XI de «La capilla»:

\footnotetext{
El interior, ¿no enseña a fundir en el ser interior y exterior? ¿Afuera no es adentro, adentro afuera, y todo espacio un solo fundamento? Salir de la capilla no era, entonces, abandonar un interior.
}

Era cruzar la sombra hasta la sombra, la luz hasta la luz. (2004: 355)

El microcosmos interior de la capilla y el mundo exterior son espacios que reflejan el «orden» macrocósmico del universo. Por eso la bóveda del templo es «como cielo labrado en la tarde de julio / por las nubes que pasan» (2004: 351). Por eso el templo todo es «alta piedra elevada sobre el limo» (2004: 354). 


\section{Alejandro Rodríguez-Refojo}

\section{La piedra}

La piedra es uno de los símbolos definitorios de la poesía de Andrés Sánchez Robayna. Podemos encontrarlo bajo distintas formas, más o menos complejas desde el punto de vista metafórico: es la «roca» y también la «piedra extrema» de la que más adelante hablaré. En su forma más simple surge en el libro Palmas sobre la losa fría, sin que por ello dejemos de advertir cómo la imagen de la piedra, omnipresente en su obra anterior y central en su libro La roca, va adquiriendo progresivamente una dimensión simbólica que resulta ya evidente en tres poemas de Palmas sobre la losa fría que llevan la imagen en el título: «A una roca», «La roca» $\mathrm{y}$, de nuevo, «A una roca». Los tres deben leerse juntos, ya que el tercero constituye una coda de los anteriores y de todo el libro.

Debido a su dureza y a la permanencia de su materia, la piedra constituye para la conciencia religiosa, según Mircea Eliade, una hierofanía. «Ante todo, la piedra es», nos dice el sabio rumano en su Tratado de historia de las religiones (2000: 332). La piedra es, por tanto, un símbolo del ser absoluto y de sus atributos: permanencia, unidad, cohesión. No constituye, para el hombre primitivo, una representación de la divinidad: es la divinidad. Este es el valor primario que tiene la imagen de la roca en los poemas mencionados, cuyos versos explicitan: «Pero tú quedas. Pero tú, visible / y secreta, te yergues nuevamente / hasta la luz del agua» (2004: 209). La roca es, en efecto, un símbolo de la unidad, la permanencia y el enigma de la realidad; es la «casa del dios oculto» (2004: 212), como dice otro de los versos. Por otro lado, la piedra como morada divina constituye, según René Guénon (1995: 137), la representación de un omphalos y, por lo tanto, un símbolo del «centro del mundo».

El poema de Robayna asume este simbolismo antiquísimo, y aunque los últimos versos de «A una roca» parecen rebatir esta interpretación, pues la roca «se yergue ante todo pasar, bajo los pies del dios» (la roca y el dios parecen, así, entidades distintas), la dualidad no es tal, sino verticalidad de los polos sobre el eje que dibujan la roca y el sol, el dios del poema. Estamos pues, de nuevo, en presencia de un axis mundi cuyo simbolismo recorre la obra entera del poeta bajo muy diferentes aspectos, y cuyo movimiento suele ser ascensional, de la sombra hacia la luz: «la claridad / es tu sentido», leemos en el último poema del libro.

Sin embargo, los diversos matices y valores que este simbolismo adopta en la poesía del autor todavía no se habían manifestado en los años de redacción de Palmas sobre la losa fría. Ese eje imantado que en la poesía del autor representa la imagen de la piedra no responde solo a las características que los estudiosos han señalado como definitorias de un «centro del mundo». En la poesía de Sánchez Robayna, ese centro se escora en un momento dado bajo la tensión del tiempo y el miedo primeros.

El poema «Una piedra, memoria», integrado en el libro Fuego blanco, da cuenta de una experiencia fundadora en la poesía y la vida del autor. Se trata de la experiencia de una salida: la del niño que sale de su casa para vagar libre por la «latitud de las parras», de pronto se le echa encima la noche y, sobre el borde del día, se para a contemplar la «arcana luz», la «suspensión de los soles sobre los platanares» (2004: 269). En ese punto, en esa precisa intersección del espacio y del tiempo 
hay que situar este poema fundamental. En ese instante, el niño-hombre graba sobre una piedra la siguiente inscripción: «A., septiembre, los soles, sobre una piedra extrema.» Recordemos que el motivo de la casa aparece en el poema como un emblema de la luz, aunque «desde aquel día supo de la sombra, o su signo.» (2004: 270). Si las imágenes de la roca y del sol se sitúan sobre la vertical en el poema «A una roca», los motivos de la casa y la piedra se sitúan ahora sobre una línea horizontal, cuyo claro simbolismo remite a las ideas de temporalidad y finitud.

El motivo de la salida adquiere en «Una piedra, memoria» la condición de mito, entendido este como «un símbolo desarrollado en forma de relato» (Ricoeur, 2011: 83). Un mito personal, en efecto, que sin embargo arraiga en el humus colectivo de los arquetipos simbólicos. Ese mito no narra otra cosa sino la entrada en la dimensión temporal de la existencia, el surgimiento de la conciencia misma del tiempo. Y en el centro del mito se halla una imagen: una piedra encontrada al final del día que acoge una serie de signos, un símbolo no solo de la permanencia y la divinidad, como se ha visto, sino también y, sobre todo, de la intersección entre la eternidad y el tiempo.

Para entender mejor el significado de la inscripción que ese niño graba sobre la piedra podemos contrastar esta situación simbólica con aquella que constituye el núcleo del poema «La estrella». Da cuenta también de la experiencia de una salida, aunque distinta de la comentada. En aquella el sujeto sale de su casa tras ver el paso fugaz de una estrella sobre el cielo nocturno mientras alguien aún duerme dentro - y se detiene a contemplar el «rastro de luz» que deja sobre la hierba del jardín y los signos nocturnos. Entonces pone su mano sobre el muro y toca el mundo, «un orden, una calma, el aire / entre el mar y la acacia» (2004: 241).

El significado de este acto, el de apoyar la mano contra el muro de la casa, no es muy distinto del acto de grabar unos pocos signos sobre una piedra extrema. Mano solar o «palabra mineral» (2004: 329), en ambos se produce una participación, aunque de distinta naturaleza: participación en el orden cósmico del que la casa es imagen, en el primer caso; participación en el misterio doloroso del dios del que la piedra es símbolo, en el segundo.

El sentido de este gesto inconsciente viene señalado no solo por el símbolo mismo, sino también por dos elementos de la escena: la situación de la piedra y el momento del día, por un lado, y la inscripción que se graba sobre ella, por otro. La piedra es símbolo del centro, pero la piedra del poema es «extrema», es decir, singular o única, pues se sitúa sobre el extremo visible del mundo y del tiempo, o, más exactamente, sobre la confluencia de ambos. Los signos oscuros grabados en ella introducen el plano del símbolo en una escena mayor cuyo significado es complejo y no fácil de interpretar. Enigmático incluso para el mismo autor, razón por la que volverá a revivir esta experiencia en el poema «Sobre una piedra extrema».

Así pues, en este poema el simbolismo de la piedra se basa en una triple característica: su situación extrema, la singularidad que le confiere haber sido receptora de signos lingüísticos y la escena que le sirve de contexto. Vale la pena detenerse en esos signos, para cuya interpretación nos serviremos del poema mencionado, «Sobre una piedra extrema». Una letra, «A.», no la inicial del nombre del autor, como en principio pudo haber pensado el lector, sino signo del inicio o del origen, 
en el sentido del alfa griego. Origen del tiempo o de la conciencia del tiempo y la muerte, pero también origen de la escritura de un libro que empezaría entonces:

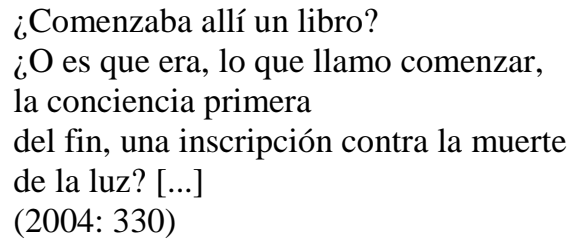

«Los soles», la fuente de esa luz que constituye un a priori de la visión poética del autor; «Septiembre», la marca temporal de la inscripción, el momento del año en que las horas de luz todavía son largas; y la referencia final, «sobre una piedra extrema», que más tarde dará título al poema y al libro homónimos. Una inscripción grabada sobre «el cuerpo del mundo» que participa de su materialidad y de su enigma; y, al mismo tiempo, una inscripción contra el tiempo y la muerte. Intersección o cruce de mundo y tiempo, de belleza y miedo, que se manifiesta igualmente en otros niveles del imaginario simbólico del poeta y que tensa su escritura entre dos polos: entre el misterio y la materia, entre la eternidad y el tiempo, entre el libro y la nada.

El significado que posee ese «cruce» recuerda el simbolismo del tejido según fue interpretado por René Guénon (2003: 98-99) en su obra El simbolismo de la cruz:

Para comprender bien el significado de este simbolismo [el del tejido], hay que comprender en primer lugar que la urdimbre, formada por los hilos tendidos sobre el telar, representa el elemento inmutable y principal, mientras que el hilo de la trama, que pasa entre los de la urdimbre con el vaivén de la lanzadera, representa el elemento variable y contingente [...]. Por otra parte, si se consideran un hilo de la urdimbre y un hilo de la trama, se ve inmediatamente que su reunión forma la cruz, de la que son respectivamente la línea vertical y la línea horizontal [...].

Más adelante Guénon (2003: 99-100) relaciona este simbolismo con la imagen del libro, revelándonos una clave de lectura de la poesía de Sánchez Robayna:

El simbolismo del tejido [...] se utiliza para representar el mundo o, más exactamente, el conjunto de los mundos, es decir, de los estados o de los grados, en multitud indefinida, que constituyen la Existencia universal [...]. Por lo demás, en realidad, hay tanta mayor relación entre estas dos aplicaciones de un mismo simbolismo cuanto que el propio Universo, en ciertas tradiciones, es simbolizado a veces mediante un libro: recordaremos tan sólo, a este respecto, el Liber Mundi de los rosacruces, y también el símbolo bien conocido del Liber Vitae apocalíptico.

Aunque es evidente que en «Una piedra, memoria» no se produce la conciliación de los opuestos que la cruz y el tejido simbolizan, pues allí la tensión permanece irresoluble, en «Sobre una piedra extrema» esa oposición parece resolverse por un instante en la metáfora del liber mundi: «Al pie de la ladera / los mundos reunidos, / como los une un libro.» (2004: 330).

No es absurdo pensar que los mundos de los que habla Guénon sean los «mundos» que aparecen en «Sobre una piedra extrema»y en otros poemas de Robayna ${ }^{2}$. Los hilos del tejido son los

\footnotetext{
${ }^{2}$ El significado que tiene la metáfora de «los mundos» en la poesía del autor, central en el poema «Más allá de los árboles» (Sobre una piedra extrema), remite también a los «innumerables mundos» que, en la visión de Giordano Bruno, alberga el cosmos.
} 
mundos del libro. Y esa conciliación, esa visión de la unidad que surge como epifanía es obra de la memoria, de la mano que protege la llama de una vela «contra el viento»:

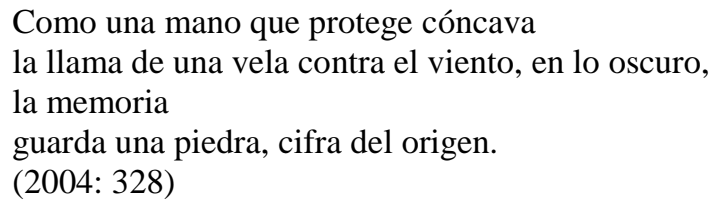

Claustro materno, concavidad que abriga la llama - como la barca abriga el fuego y la casa la estrella — de la «disolución ... en las Aguas» (Sánchez Robayna, 1996: 81). La caída en el tiempo significó un comienzo. El comienzo del tiempo mismo y la primera palabra de un libro. Palabramemoria inscrita en la memoria de la piedra.

\section{El libro del mundo}

No es este el lugar para explicar el significado y el alcance que la imagen del 'Gran Libro del Mundo' tiene en nuestra cultura. Curtius y Blumenberg han dedicado páginas penetrantes a ello. Baste recordar que el liber mundi es un motivo central en las llamadas culturas del libro. La Torá, La Biblia y el Corán son los arquetipos de cualesquiera otros libros en cuanto son la verdad revelada. No se trata de una metáfora arrumbada por la cultura contemporánea, pues sigue desempeñando una función esencial en el lenguaje de la genética: el ADN es un libro de instrucciones que se transcribe y se traduce, si bien en ese lenguaje prevalece un sentido instrumental.

Las fascinantes ramificaciones de esta imagen pasaron a la poesía moderna a través del Romanticismo y luego de Baudelaire y Mallarmé, y ya desempeñan, según Sánchez Robayna, un importante papel en las Soledades de Góngora como «manifestación [barroca] de la moderna autonomía del arte» (1993: 54). El poeta canario ha hecho de esta «metáfora absoluta» el pivote sobre el que gira toda su poesía y su reflexión sobre el lenguaje poético: «si el mundo, en efecto, es un libro, el libro es un mundo» (1993: 54).

Para sintetizar el valor y el significado que esta imagen-eje posee en la obra del autor, citaré una reflexión de Levinas. Para el autor de Totalidad e infinito, el libro no es «una fuente de informaciones, o un "utensilio" del aprender, un manual, [...] es una modalidad de nuestro ser» (2000: 23-34). Totalmente alejado de la visión instrumental que del libro tiene nuestra sociedad, Sánchez Robayna no lo concibe como una fuente de información, ni siquiera de conocimiento en el sentido en que tal concepto es manejado hoy, sino, en efecto, como una modalidad del ser, la casa en la que habita el poeta, el centro desde el cual este se pregunta por el mundo y la palabra. La pregunta es, de hecho, la casa misma: «como si sólo la pregunta fuera / la casa que habitamos, / nuestro aire / en la respiración entre lo uno.» (2004: 333). En el tópico del liber mundi subyace, así pues, una concepción del mundo y del libro gobernada por una doble visión: la de la unidad y la del enigma. Por eso puede decirse que En el cuerpo del mundo (2004) es un libro que contiene, entretejidos, los mundos del poeta, los tiempos de su escritura, y que, tal vez, seguirá incluyéndolos. 
En ese libro hay dos condensaciones, por decirlo así, de esta metáfora de metáforas. La primera, de carácter espacial, está contenida en los ya citados versos: «Al pie de la ladera / los mundos reunidos, / como los une un libro» (2004: 330), y es deudora tanto del dictum de Mallarmé, Le monde est fait pour aboutir à un beau livre (Scherer, 1978: 151), como de los versos famosos de Dante, «con amor en un libro encuadernado, / lo que en el orbe se desencuaderna» (Paraíso, XXXIII, 86-87, trad. Ángel Crespo, 1986). La segunda condensación es de índole temporal y hay que buscarla en el fragmento XXXV de El libro, tras la duna; fragmento axial en el que este libro gira sobre sí mismo y pasa a orientarse no hacia el pasado, sino hacia el futuro, y cuyo verso final, «verá formarse el libro, tras la duna» (2004: 392), apunta el término último de la obra, una vez concluida la obra del tiempo.

\section{El símbolo, la memoria y lo sagrado}

La obra poética de Andrés Sánchez Robayna no se habría abierto al universo plurisignificante del símbolo si no hubiera concebido la posibilidad de una palabra liberada del lenguaje. Esa posibilidad, postulada por María Zambrano, la de una palabra que «mira y se encarna más allá del lenguaje» según el autor (1996: 246), presupone un afuera del lenguaje. A ese «afuera» señalan los símbolos de la barca, la casa, la piedra y otros no analizados aquí (de modo muy concreto el símbolo de «los árboles» del poema «Más allá de los árboles»). Preñado de significaciones, el símbolo apunta siempre a un sentido más allá del lenguaje que, sin embargo, solo este posibilita — paradoja que brilla en la citada definición de Durand («el símbolo es ... la epifanía de un misterio»).

Tanto el símbolo como esta palabra «que mira y se encarna más allá del lenguaje» (Sánchez Robayna, 1996: 246) convergen en una exploración poética que lleva al autor a concebir su trabajo cada vez más cercano a la sensibilidad místico-religiosa. Estrechamente vinculadas a una concepción de lo poético como misteriosofía o conocimiento negativo, la barca, la isla, la casa y la piedra son imágenes que apuntan, en efecto, al surgimiento de una conciencia simbólica y, por consiguiente, religiosa del mundo.

Emplearé el término lo sagrado para distinguir esa «conciencia religiosa» (Eliade, 2008: 345) de la esfera eclesial o confesional, habida cuenta de las reticencias que aún hoy suscitan entre nosotros cualquier apelación a lo religioso o lo místico. El concepto de lo sagrado fue acuñado para explicar el núcleo del fenómeno religioso. En palabras de Roger Caillois (1996: 12), se trata de «una categoría de la sensibilidad [...] sobre la que descansa la actitud religiosa».

A mi entender, el sentimiento de lo sagrado se manifiesta en la poesía de Robayna sobre todo en la presencia del símbolo, pero también en la indagación en torno a los signos escritos por el tiempo en el «libro de la memoria». Ahí está la raíz del proceso creador que lleva al surgimiento de la conciencia de la sacralidad del mundo en la poesía de Robayna - a la que el poeta se refiere en ocasiones en los términos de un «designio de religación» (2008: 345), de unión con el mundo. 
Comentando un trabajo de Tierno Galván sobre la cultura barroca en el que este afirma que «la intimidad se construye como una secularización de la conciencia religiosa», Sánchez Robayna escribe que esa idea, la de que «la intimidad es una traducción de lo religioso» (1996:143), está clara para él desde hace tiempo. Robayna continúa su reflexión en este apunte de 1989, pero interesa detenernos en este asunto. En un apunte de 1990 vuelve sobre ello: «desde algún tiempo atrás, no concibo o no podría concebir ninguna escritura ajena a la idea y al espacio de sacralidad» (1996: 200). A continuación concluye, recordando tal vez el cuadro La barca mística de Odilon Redon: «El poema es una barca mística.» (1996: 201). Y más adelante, añade que la poesía es «la tierra de la memoria»; más aún, la poesía es «un cosmos "gobernado por lo irreal-real"» (1996: 201-202). He aquí de nuevo la imagen de la barca, símbolo de la memoria, y la palabra poética como imagen del cosmos.

A través de la poesía y las reflexiones del poeta nos asomamos, así, a una de las facetas más asombrosas de la memoria humana. En tanto continuidad o persistencia en el tiempo frente a la disolución y la muerte, la memoria es piedra del alma: expresa la verdad de nuestro ser y nuestra intimidad. La memoria es, además, un modo de conocimiento negativo o de conocimiento por enigma, pues no se confunde con lo vivido como algo dado, como sustancia conocida, ni se opone a los olvidos necesarios de nuestra existencia.

Por otro lado, la memoria está ligada de modo inseparable al sentimiento y la conciencia de temporalidad de la existencia. En El libro, tras la duna, la memoria y el tiempo caminan de la mano, pero es aquella la medida de lo vivido:

Memoria que atesoras
y nutres lo vivido:
naciste al mismo tiempo que la noche
en que andamos oscuros.
En ti mido los tiempos $[\ldots]$
$(2004: 374)$

En ese movimiento interior de la memoria que se abre al mundo — «barca de fuego» que avanza hacia la isla-, subsiste transformado, en mi opinión, el sentimiento de lo sagrado arcaico.

El simbolismo del centro traduce precisamente este sentido de lo sagrado, que, obviamente, no es en absoluto exclusivo del autor. Es posible encontrarlo en numerosos poetas y artistas desde el Romanticismo hasta nuestros días. Ramon Xirau estudió su rastro en la poesía de Juan Ramón Jiménez y de César Vallejo. En su ensayo Dos poetas y lo sagrado (1980), Xirau nos recuerda que «la presencia de un centro es fundamental para cualquier idea de lo sagrado. El centro puede ser nuestro mundo, puede ser el templo o pueden serlo el muro, el árbol, la casa» (2001: 232). La casa, la capilla, la isla o la barca son, en resumen, símbolos de un centro corpóreo del mundo en el que la poesía de Sánchez Robayna desea inscribirse. El motivo del «libro del mundo» no es ajeno a este deseo y a esta visión. La concepción del mundo y del libro como enigma, como mensaje cifrado, presupone una perspectiva religiosa de la existencia. 
El símbolo de la piedra acaso constituya el fundamento simbólico de la obra poética del autor. ¿Sería exagerado afirmar que, para Robayna, esa piedra - central y extrema a un tiempo- está saturada de ser, posee mana? No lo creo. Precisamente por eso puede llegar a ser sagrada para el poeta. Y aunque Eliade insistió mucho en separar la experiencia estética del hombre actual de la experiencia sagrada del hombre primitivo, no es menos cierto que hay algo común a ambas que las hermana y que fundamenta su proximidad. Me atrevería a decir que la experiencia creadora del poeta y del artista modernos que buscan un «centro del mundo» no constituye el residuo de una visión sagrada del mundo — «la reminiscencia de una experiencia religiosa degradada», en palabras de Eliade (2008: 113) — , sino una forma de la existencia en que lo sagrado, como experiencia humana primordial, se conserva y se reinterpreta permanentemente.

\section{Bibliografía:}

Alighieri, D. (1986): Comedia. Barcelona, Planeta.

BACHElARD, G. (2000): La poética del espacio. México, Fondo de Cultura Económica. (2003): El agua y los sueños. México, Fondo de Cultura Económica.

CIRLOT, J. E. (1997): Diccionario de símbolos. Madrid, Siruela.

DURAND, G. (2007): La imaginación simbólica. Buenos Aires, Amorrortu.

EliAde, M. (2000): Tratado de historia de las religiones: morfología y dialéctica de lo sagrado. Madrid, Ediciones Cristiandad.

- (2008): Lo sagrado y lo profano. Barcelona, Paidós.

ESQUIROL, J. M. (2015): La resistencia íntima: ensayo de una filosofía de la proximidad. Barcelona, Acantilado.

GuÉNON, R. (1995): Símbolos fundamentales de la ciencia sagrada. Barcelona, Paidós.

- (2003): El simbolismo de la cruz. Palma de Mallorca, José J. de Olañeta.

HANI, J. (2005): Mitos, ritos y símbolos: los caminos hacia lo invisible. Palma de Mallorca, José J. de Olañeta.

LEVINAS, E. (2000): Ética e infinito. Madrid, Antonio Machado Libros.

ORY, C. E. de (2005): Los aerolitos. Madrid, Calambur.

RICOEUR, P. (2011): Finitud y culpabilidad. Madrid, Trotta.

SÁnchez RoBAYNA, A. (1993): Silva gongorina. Madrid, Cátedra. (1996): La inminencia (diarios, 1980-1995). México, Fondo de Cultura Económica.

- (2004): En el cuerpo del mundo: obra poética, 1970-2002. Barcelona, Galaxia Gutenberg.

- (2008): Deseo, imagen, lugar de la palabra. Barcelona, Galaxia Gutenberg.

- (2010): La sombra y la apariencia. Barcelona, Tusquets.

SCHERER, J. (1978): Le «Livre» de Mallarmé. París, Gallimard.

TAtARKIEWICZ, W. (2007): Historia de la estética. Vol. II. Madrid, Akal. 
Tur Planells, H. (2006): La imagen del mar a través de textos poéticos del Modernismo grancanario. Santa Cruz de Tenerife, Idea.

XIRAU, R. (2001): Entre la poesía y el conocimiento: antología de ensayos críticos sobre poetas y poesía iberoamericanos. México, Fondo de Cultura Económica. 